\title{
Use of Therapeutic Hypothermia in Sudden Unexpected Postnatal Collapse: A Retrospective Study
}

\author{
Uso de Hipotermia Induzida no Colapso Súbito \\ Pós-Natal: Um Estudo Retrospetivo
}

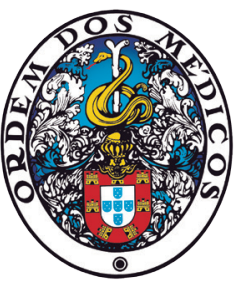

\author{
Sara BRITO $\rrbracket^{1}$, Isabel SAMPAIO², Alexandra DINIS ${ }^{3}$, Elisa PROENÇA4 ${ }^{4}$, Ana VILAN ${ }^{5}$, Eunice SOARES ${ }^{1}$, \\ Filomena PINTO' 1 , Teresa TOMÉ 1 , André M. GRAÇA ${ }^{2,6}$ \\ Acta Med Port 2021 Jun;34(6):442-450 - https://doi.org/10.20344/amp.13767
}

\section{ABSTRACT}

Introduction: Sudden and unexpected postnatal collapse is a rare event with potentially dramatic consequences. Intervention approaches are limited, but hypothermia has been considered after postnatal collapse. The aim of this study was to analyse sudden and unexpected postnatal collapse cases that underwent therapeutic hypothermia in the five Portuguese hypothermia centres.

Material and Methods: In this multicentre, retrospective and descriptive study, clinical, ultrasonography, amplitude-integrated electroencephalography and brain magnetic resonance findings of newborns with postnatal collapse that underwent therapeutic hypothermia are reported (2010 - 2018). Statistical analysis was performed by using IBM SPSS Statistics version 21.

Results: Twenty-two cases of sudden and unexpected postnatal collapse were referred for therapeutic hypothermia (82\% outborn), all $\geq 36$ weeks, with Apgar $5^{\prime} \geq 8$. Collapse occurred during the first two hours in $73 \%$ (all $<24$ hours), $50 \%$ during skin-to-skin care, $55 \%$ related to feeding and $23 \%$ during co-bedding. Moderate-severe encephalopathy and severe acidosis were observed (median: Thompson score 16, pH 6.90, base deficit $22 \mathrm{mmol} / \mathrm{L}$ ). Amplitude-integrated electroencephalogram was abnormal in $95 \%$ and magnetic resonance imaging showed severe brain injury in $46 \%$. The mortality rate was $50 \%$. A possible cause was identified in $27 \%$.

Discussion: The incidence rate of 2.7 sudden cases of postnatal collapse per 100000 births, is possibly under-estimated. All infants suffered the collapse in the first day, mostly within the first two hours, as reported before. Possible causes were identified in less than a third of cases, but multiple predisposing conditions were identified, suggesting that prevention may be possible. Newborn positioning and skin-to-skin care have been the most discussed practices. A significant proportion of infants had poor outcomes. Lower Thompson score, electroencephalogram amplitude normalization and normal magnetic resonance imaging seemed to indicate better outcomes. Although conclusive trials on therapeutic hypothermia after postnatal collapse are not available, its use has been considered individually. No severe adverse effects directly related to hypothermia were registered in this study, but the results do not allow drawing meaningful conclusions.

Conclusion: In our national sample of 22 infants who suffered sudden and unexpected postnatal collapse and underwent therapeutic hypothermia, a significant proportion had poor outcomes. Absolute conclusions from our experience with hypothermia in postnatal collapse cannot be drawn, but systematic reporting of cases and long-term clinical evaluation would facilitate understanding of the real benefits of hypothermia. As this procedure has not been validated with clinical trials for this indication, its use should be considered on a case-by-case approach. The potentially avoidable nature of unexpected postnatal collapse is evident from its association with certain behaviours and risk factors. Surveillance practices during the first hours should be implemented, whilst the benefits of breastfeeding and skin-to-skin care should continue to be widely promoted.

Keywords: Hypothermia, Induced; Hypoxia-Ischemia, Brain/therapy; Infant, Newborn; Kangaroo-Mother Care Method

\section{RESUMO}

Introdução: O colapso pós-natal súbito inesperado, apesar de raro, condiciona potenciais consequências dramáticas. As intervenções terapêuticas são limitadas, mas a hipotermia induzida tem sido considerada após estes eventos. O objetivo deste estudo foi analisar os casos de colapso pós-natal súbito inesperado submetidos a hipotermia induzida nos cinco centros portugueses que a realizam.

Material e Métodos: Estudo descritivo retrospetivo multicêntrico dos recém-nascidos submetidos a hipotermia induzida após colapso pós-natal entre 2010 e 2018. Foram analisadas as variáveis clínicas, a monitorização por eletroencefalograma de amplitude integrada e imagem por ultrassonografia e a ressonância magnética cerebral. A análise estatística foi efetuada com apoio do IBM SPSS Statistics version 21.

Resultados: Foram submetidos a hipotermia terapêutica por colapso súbito 22 recém-nascidos, $82 \%$ outborn, todos com 36 ou mais semanas de gestação e Apgar 5' $\geq 8$. A situação ocorreu nas primeiras duas horas de vida em $73 \%$ (todos com menos de 24 horas de vida), $50 \%$ no contacto pele-a-pele, $55 \%$ associados à amamentação e $23 \%$ durante partilha de cama. Os recém-nascidos observados apresentaram encefalopatia moderada a grave e acidose grave (mediana: Thompson 16, pH 6,90, défice bases $22 \mathrm{mmol} / \mathrm{L}$ ). Entre os recém-nascidos, $95 \%$ registaram alteração no eletroencefalograma e $46 \%$ padrões graves de ressonância cerebral. A taxa de mortalidade foi de $50 \%$. Identificaram-se possíveis causas em $27 \%$.

Discussão: Estimou-se uma incidência de 2,7 casos de colapso pós-natal súbito inesperado por cada 100000 nascimentos, um valor possivelmente subestimado. O colapso ocorreu no primeiro dia em todas as crianças, a maioria nas primeiras duas horas, tal como

1. Serviço de Neonatologia. Área de Pediatria Médica. Maternidade Dr. Alfredo da Costa. Centro Hospitalar Universitário de Lisboa Central. Lisboa. Portugal.

2. Serviço de Neonatologia. Departamento de Pediatria. Hospital de Santa Maria. Centro Hospitalar Universitário Lisboa Norte. Lisboa. Portugal.

3. Unidade de Cuidados Intensivos Pediátricos. Hospital Pediátrico de Coimbra. Centro Hospitalar e Universitário de Coimbra. Coimbra. Portugal.

4. Unidade de Cuidados Intensivos Neonatais. Centro Hospitalar Universitário do Porto. Porto. Portugal.

5. Serviço de Neonatologia. Hospital Pediátrico Integrado. Centro Hospitalar Universitário de São João. Porto. Portugal.

6. Clínica Universitária de Pediatria. Faculdade de Medicina. Universidade de Lisboa. Lisboa. Portugal.

$\triangle$ Autor correspondente: Sara Brito. sarabri@gmail.com

Recebido: 22 de março de 2020 - Aceite: 28 de setembro de 2020 - First published: 22 de abril de 2021 - Online issue published: 01 de junho de 2021 Copyright @ Ordem dos Médicos 2021 
descrito em publicações anteriores. Identificaram-se possíveis causas em menos de um terço dos casos, mas múltiplas condições predisponentes foram referidas, o que sugere a possibilidade de adoção de medidas preventivas. O posicionamento do recém-nascido e o contacto pele-a-pele têm sido as práticas mais discutidas. Uma proporção significativa das crianças teve uma evolução desfavorável. Um desfecho mais positivo parece ter ocorrido nos casos em que se verificaram valores inferiores na escala de Thompson, normalização do eletroencefalograma de amplitude integrada e ressonância magnética normal. Embora não estejam disponíveis ensaios conclusivos sobre a utilização da hipotermia terapêutica após o colapso pós-natal, o seu uso tem sido considerado individualmente. Nesta revisão não foram observados efeitos adversos diretamente relacionados com o procedimento, mas os resultados não permitem obter conclusões significativas.

Conclusão: Na nossa amostra nacional de 22 crianças que sofreram colapso súbito pós-natal e submetidas a hipotermia terapêutica, uma proporção significativa teve uma evolução desfavorável. A nossa experiência e a raridade da entidade clínica não permitem delinear conclusões precisas sobre a aplicação da hipotermia induzida no colapso pós-natal súbito inesperado, pelo que se considera essencial a prevenção. O benefício desta terapêutica poderá ser clarificado através do registo sistemático dos casos e do seguimento a longo prazo das crianças. Embora não existam ensaios clínicos que permitam a sua validação após estes eventos, a hipotermia induzida deve ser uma opção a considerar individualmente. A associação do colapso pós-natal com determinados comportamentos e fatores de risco evidenciam a sua potencial prevenção. Devem ser implementadas estratégias de monitorização nas primeiras horas de vida que permitam simultaneamente a contínua promoção da amamentação e do contacto pele-a-pele.

Palavras-chave: Hipotermia Induzida; Hipóxia-Isquemia Encefálica; Método Canguru; Recém-Nascido

\section{INTRODUCTION}

The sudden and unexpected postnatal collapse (SUPC) of a presumably healthy term newborn is a rare event, associated with potentially catastrophic consequences. ${ }^{1,2}$ It may represent the first manifestation of a congenital anomaly, infection or metabolic disorder, but in most cases no underlying condition is identified, and it seems to have a complex pathophysiology, which is still poorly understood..$^{1,3}$

It is generally characterized by apnoea, hypotonia, pallor, bradycardia, cyanosis, collapse and cardiac or respiratory failure. ${ }^{1-5}$ Despite increasing awareness of SUPC as a clinical entity, there is not a consensual definition. ${ }^{3}$ Guidelines endorsed by the British Association of Perinatal Medicine in 2014 defined SUPC as "a term or near-term infant who is well at birth, assigned to routine postnatal care and who collapses unexpectedly within the first seven days of life, requiring resuscitation with intermittent positive pressure ventilation and who either dies, requires ongoing intensive care or develops encephalopathy"., 6,7 This definition is increasingly accepted across the perinatal community.

There are now over 400 cases described in the medical literature mentioning a variable incidence of all-cause SUPC. Recent population-based studies estimate an incidence of 2.6 - 38.0 cases per 100000 live births. ${ }^{1,3,4,8-11}$ This wide interval can be attributed to differences in definition and inclusion criteria, including gestational and postnatal age and severity of the collapse (with milder cases being excluded from most studies), suggesting that this situation is underreported. ${ }^{3,4,6}$

One-third of SUPC cases tend to occur in the first two hours after birth, another third between two and 24 hours and the last third between one and seven postnatal days..$^{5,10}$ Earlier studies highlighted an even earlier occurrence, varying between $55 \%$ and $73 \%$ within the first and second postnatal hours. ${ }^{1,4}$

Although no cause is found for the majority of cases, multiple predisposing conditions have been identified, such as co-bedding, prone position and impaired maternal awareness, therefore suggesting the possibility of preventive strategies. ${ }^{6}$

Skin-to-skin contact (SSC), recommended for all healthy term newborns by some authorities (World Health
Organization, American Academy of Pediatrics, American College of Obstetricians and Gynecologists, Centers for Disease Control and Prevention, Academy of Breastfeeding Medicine, United Nations International Children's Emergency Fund), ${ }^{12,13}$ has multiple beneficial effects on infants and their families. ${ }^{12-16}$ It contributes to improved temperature regulation, allows better cardio-respiratory stability and glycemic control, reduces infant discomfort and promotes success of breastfeeding. , $^{211-16}$ Immediate SSC also influences microbiota colonization of the newborn ${ }^{16}$ and, simultaneously, improves parental bonding and maternal clinical recovery. ${ }^{2,13-16}$

Despite those recommendations, the practice of SSC at birth is still not globally widespread, probably due to a lack of knowledge about its benefits, absence of a standardized method or uniform practice, occasional unfamiliarity with the adequate assessment of the mother-infant dyad and their safe positioning, and lack of training on the regular physiologic monitoring that is required and on the measures to minimize potential complications. ${ }^{12,14}$ According to some reviews, this intervention is not associated with short or long-term negative effects. ${ }^{13,15}$ Nonetheless, SUPC has been considered an emerging complication of SSC and breastfeeding, from the first hours to the first days after birth ${ }^{13,14}$ and its rising incidence might be attributed to the gradual implementation of these practices.

It is, therefore, necessary, to identify possible risk factors favoring hypoxic events and to implement preventive assessment tools, which could facilitate comfort, knowledge and competence in assessing infants and ensuring their safety during SSC and breastfeeding.

Although SUPC is infrequent, it is associated with high mortality rates and long-term disability in more than half of the survivors. ${ }^{3,4,6,10,14}$ Moreover, therapeutic approaches to prevent such unfavourable outcomes are limited.

Considering the safety of therapeutic hypothermia $(\mathrm{TH})$ and pathophysiologic similarity between neonatal hypoxicischaemic encephalopathy (HIE) and the hypoxic-ischaemic insult in SUPC, TH has been considered in some neonatal intensive care units (NICU) as a therapeutic approach.,17-19 Despite lack of evidence or randomized controlled trials to 
support its benefits in SUPC, its use is being extensively described. . $^{17,19-24}$

The aim of this study was to review all the SUPC cases that underwent $\mathrm{TH}$ retrospectively and assess the circumstances of the events and their short-term outcomes. Secondly, we aimed to identify potential prognostic indicators. We intended to point out possible preventive strategies in the immediate postnatal period and to ascertain the eventual role of $\mathrm{TH}$ in ameliorating long term neurological injury.

\section{MATERIAL AND METHODS}

We performed a descriptive and multicentre study, including term and near-term newborns with SUPC needing advanced resuscitation, who underwent $\mathrm{TH}$ in the five Portuguese neonatal referral centres, between 2010 and 2018.

We included newborns referred to the perinatal centres in the first six hours after cardio-respiratory collapse, who presented with moderate to severe encephalopathy (altered level of consciousness, tone, reflexes, or respiratory drive) or severe metabolic acidosis $(\mathrm{pH}<7.00$ or base excess $<$ $-16 \mathrm{mmol} / \mathrm{L}$ ), who could potentially benefit from therapeutic hypothermia (exceptional indication considered).

Parents were informed and consent was obtained prior to the beginning of cooling, either in the written form or verbally, so as not to delay treatment in case they were not immediately present. In some situations, consent was primarily presumed on the grounds of urgency in treatment, and verified later on. There were no parental objections to treatment.

Clinical data were collected retrospectively from medical records, concerning information on pregnancy and birth, circumstances of the event, laboratory data and investigation to exclude a possible underlying disease with infection, metabolic and cardiac screening, continuous amplitudeintegrated electroencephalography (aEEG) monitoring, cranial ultrasound (C-US), brain magnetic resonance imaging (MRI), clinical evolution in the Neonatal Intensive Care Unit (NICU) and neurological examination at discharge. Surviving and non-surviving newborns were compared.

Whole-body cooling at core target temperature $33.5^{\circ} \mathrm{C}$ for 72 hours was used. The whole procedure and clinical, radiological and laboratory monitoring were applied according to the Portuguese Society of Neonatology protocol for perinatal HIE. ${ }^{25}$

The aEEG monitoring was performed using one or twochannel systems.

Background activity was classified using a voltage classification (Naqeeb et al), as ${ }^{26,27}$ :

1. Normal: upper margin of band of aEEG activity $>10$ $\mathrm{mV}$ and lower margin $>5 \mathrm{mV}$;

2. Moderately abnormal: upper margin $>10 \mathrm{mV}$ and lower margin $<5 \mathrm{mV}$;

3. Severely abnormal: upper margin $<10 \mathrm{mV}$ and lower margin $<5 \mathrm{mV}$, possibly accompanied by bursts of high voltage activity (burst suppression).

Any of these three groups could be accompanied by seizures. $^{26}$
The aEEG pattern was additionally described according to Hellstrom-Westas et al as ${ }^{27,28}$ :

1. Normal - continuous normal voltage/CNV: continuous activity with upper margin $>10 \mathrm{mV}$ and lower margin > $5 \mathrm{mV}$;

2. Normal - discontinuous normal voltage/DNV: discontinuous activity with upper margin $>10 \mathrm{mV}$ and variable lower margin but $<5 \mathrm{mV}$;

3. Abnormal - burst-suppression/BS: discontinuous activity with minimum amplitude without variability and bursts with margin > $25 \mathrm{mV}$;

4. Abnormal - low voltage/LV: continuous background pattern of very low voltage $\leq 5 \mathrm{mV}$;

5. Abnormal - flat trace/FT: isoelectric tracing $<5 \mathrm{mV}$.

Encephalopathy was classified in agreement with Sarnat et al. ${ }^{29}$ The Thompson encephalopathy score was calculated regularly during the treatment period using the criteria specified by Thompson et al. ${ }^{30}$ Hemodynamic dysfunction was defined for patients who needed fluid, vasopressor or inotropic support. Respiratory dysfunction was not mentioned, since most patients underwent mechanical ventilation in order to complete $\mathrm{TH}$. Acute kidney injury was defined as serum creatinine $\geq 1.5 \mathrm{mg} / \mathrm{dL}$ or a rise $>0.3 \mathrm{mg} /$ dL/day.

Statistical analysis was performed by using IBM SPSS Statistics version 21 . The $X 2$ test and the Fisher exact test were used for categorical variables and the Mann-Whitney $U$ test was used for continuous variables. A $p$ value of $<0.05$ was considered statistically significant.

Ethics Committee approval was not specifically requested. The authors confirm that data were collected retrospectively and anonymously in each medical institution according to personal data privacy rules. In addition, we emphasize that the study was conducted in accordance to the ethical principles expressed in the Declaration of Helsinki, the Portuguese law and Good Clinical Practice guidelines.

\section{RESULTS}

During the study period (2010 - 2018), 22 cases of SUPC were referred for TH ( $82 \%$ of them were outborn). All of them were term or near-term infants (median 39 weeks, all over 36 weeks) and most had adequate birthweight (median $3100 \mathrm{~g}$; range 2335 - $4250 \mathrm{~g}$ ). No significant gender predominance was noticed (female $55 \%$ ). All newborns had an Apgar score over seven at five minutes after birth. They were born to vaginal delivery in $73 \%$ (50\% non-instrumental vaginal delivery).

Mean maternal age was $29 \pm 7$ years (median 28.5; range 17 - 39), 86\% were primiparous and adequate obstetric surveillance was noted in $91 \%$ of the cases. Pregnancy was uneventful in $64 \%$, the remainder having risk factors such as gestational diabetes (14\%), gestational induced hypertension $(5 \%)$, maternal arrhythmia $(5 \%)$, foetal growth restriction $(5 \%)$, toxoplasma serological conversion $(5 \%)$, maternal hypothyroidism (5\%), maternal depressive disorder $(5 \%)$ and family history of sudden death (5\%). Neonatal demographic characteristics, as well as pregnancy and 
Table 1 - Newborn demographic data and delivery circumstances

\begin{tabular}{|c|c|c|c|c|}
\hline & $\begin{array}{l}\text { Survivors } \\
(n=11)\end{array}$ & $\begin{array}{l}\text { Non-survivors } \\
\quad(n=11)\end{array}$ & $\begin{array}{c}\text { Total } \\
(n=22)\end{array}$ & $p$ value \\
\hline Gestational age, weeks* & $\begin{array}{c}39 \\
(38-40)\end{array}$ & $\begin{array}{c}39 \\
(38-40)\end{array}$ & $\begin{array}{c}39 \\
(38-40)\end{array}$ & n.s. \\
\hline Birthweight, grams* & $\begin{array}{c}3040 \\
(2745-3450)\end{array}$ & $\begin{array}{c}3130 \\
(2665-3535)\end{array}$ & $\begin{array}{c}3100 \\
(2669-3471)\end{array}$ & n.s. \\
\hline Female, \% & 54.5 & 54.5 & 54.5 & n.s. \\
\hline Pregnancy surveillance, $\%$ & 90.9 & 90.9 & 90.9 & n.s. \\
\hline Pregnancy disorders, \% & 18.2 & 54.5 & 36.4 & n.s. \\
\hline Mother's age, years* & $\begin{array}{c}28 \\
(26-32)\end{array}$ & $\begin{array}{c}29 \\
(21-38)\end{array}$ & $\begin{array}{c}28.5 \\
(22.7-35.5)\end{array}$ & n.s. \\
\hline Primiparity, \% & 100 & 72.7 & 86.4 & n.s. \\
\hline Outborn, \% & 81.8 & 81.8 & 81.8 & n.s. \\
\hline Vaginal delivery, $\%$ & 72.7 & 72.7 & 72.7 & n.s. \\
\hline Apgar $1^{\text {st }} \min \geq 8, \%$ & 100 & 81.8 & 90.1 & n.s. \\
\hline Apgar $5^{\text {th }} \min \geq 8, \%$ & 100 & 100 & 100 & n.s. \\
\hline
\end{tabular}

* Median (InterQuartile Range)

Table 2 - Sudden unexpected collapse circumstances

\begin{tabular}{|c|c|c|c|c|}
\hline & $\begin{array}{c}\text { Survivors } \\
(\mathrm{n}=11)\end{array}$ & $\begin{array}{c}\text { Non-survivors } \\
(n=11)\end{array}$ & $\begin{array}{c}\text { Total } \\
(n=22) \\
\end{array}$ & $p$ value \\
\hline Time post-birth to SUPC, hours* & $\begin{array}{c}1.0 \\
(0.5-1.8)\end{array}$ & $\begin{array}{c}2.0 \\
(1.0-4.0)\end{array}$ & $\begin{array}{c}1.6 \\
(0.95-2.6)\end{array}$ & n.s. \\
\hline Time post-SUPC to start TH, hours* & $\begin{array}{c}4.5 \\
(2.0-7.6)\end{array}$ & $\begin{array}{c}4.0 \\
(2.0-5.9)\end{array}$ & $\begin{array}{c}4.4 \\
(2.0-6.4)\end{array}$ & n.s. \\
\hline Resuscitation, \% & & & & n.s. \\
\hline - Intubation and PPV & 100 & 100 & 100 & \\
\hline - Cardiac compressions & 72.7 & 81.8 & 77.3 & \\
\hline - Drugs & 63.6 & 72.7 & 68.2 & \\
\hline Unsafe scenario, $\%$ & 54.5 & 63.6 & 59.1 & n.s \\
\hline Association to feeding, $\%$ & 63.6 & 45.5 & 54.5 & - \\
\hline \multicolumn{5}{|l|}{ Place of occurrence, $\%$} \\
\hline - Skin-to-skin contact & 45.4 & 54.5 & 11.0 & \\
\hline - Co-bedding & 18.2 & 27.3 & 22.7 & \\
\hline - Cot & 9.1 & 0.0 & 4.6 & \\
\hline - Unknown & 27.3 & 18.2 & 22.7 & - \\
\hline
\end{tabular}

PPV: positive pressure ventilation; SUPC: sudden unexpected postnatal collapse; TH: therapeutic hypothermia

${ }^{*}$ Median (InterQuartile Range)

delivery circumstances are displayed in Table 1 .

Table 2 describes chronological, clinical and circumstances related to sudden unexpected postnatal collapse (SUPC) cases.

Both surviving and non-surviving newborns were compared.

All newborns suffered an unexpected collapse needing resuscitation during the first day of life, at a median of 98 minutes (median 1.6 hours, range 0.3 - 23) and $73 \%$ occurred in the first two hours of life.

All the patients required advanced life support including intubation and positive pressure ventilation. Chest compressions were performed in $77 \%$ and $68 \%$ required drugs for resuscitation.

The event occurred during early SSC with mother/fa- ther in $50 \%$ of newborns and $23 \%$ were co-bedding with the mother. There was a chronological relationship with feeding in more than half (14\% immediately before, $18 \%$ during and $23 \%$ immediately after breastfeeding).

The scenario where patients were found was considered unsafe in $59 \%$, due to infant position (lying prone, on mother's breast or abdomen with vulnerable airway patency), mother's anaesthesia or mother's distractibility.

On admission at the tertiary perinatal centre, $91 \%$ showed signs of moderate (32\%) or severe encephalopathy (59\%) (Table 3). Severe metabolic acidosis was universally present, with median values of 6.9 for $\mathrm{pH}$ (range 6.7 - 7.17) and $22 \mathrm{mmol} / \mathrm{L}$ for base deficit (range 6 - 27). Maximum median Thompson score was 16 (range 5 - 20).

$\mathrm{TH}$ was started at a median of six hours after birth (range 
Table 3 - Clinical and diagnostic evaluation after SUPC, during hospital stay

\begin{tabular}{|c|c|c|c|c|}
\hline & $\begin{array}{c}\text { Survivors } \\
(n=11)\end{array}$ & $\begin{array}{c}\text { Non-survivors } \\
(n=11)\end{array}$ & $\begin{array}{c}\text { Total } \\
(n=22)\end{array}$ & $p$ value \\
\hline Severe encephalopathy, \% & 27.3 & 90.9 & 59.1 & - \\
\hline Worst Thompson score* & $\begin{array}{c}12.5 \\
(6.2-14.5)\end{array}$ & $\begin{array}{c}17.0 \\
(16-18.5)\end{array}$ & $\begin{array}{c}16.0 \\
(12.5-17.5)\end{array}$ & $<0.005$ \\
\hline Worst $\mathrm{pH}^{*}$ & $\begin{array}{c}7.0 \\
(6.86-7.09)\end{array}$ & $\begin{array}{c}6.84 \\
(6.80-6.90)\end{array}$ & $\begin{array}{c}6.90 \\
(6.80-7.02)\end{array}$ & $<0.05$ \\
\hline Worst base deficit, $\mathrm{mEq} / \mathrm{L}^{*}$ & $\begin{array}{c}20 \\
(14.8-22)\end{array}$ & $\begin{array}{c}24.7 \\
(22-26)\end{array}$ & $\begin{array}{c}22.0 \\
(17.0-25.5)\end{array}$ & $<0.05$ \\
\hline Maximum LDH, U/L* & $\begin{array}{c}890 \\
(712-3113)\end{array}$ & $\begin{array}{c}1759 \\
(1094-4905)\end{array}$ & $\begin{array}{c}1593 \\
(889-3938)\end{array}$ & n.s. \\
\hline Hemodynamic instability, $\%$ & 54.5 & 72.7 & 63.6 & n.s. \\
\hline Acute kidney failure, $\%$ & 27.3 & 36.4 & 31.8 & n.s. \\
\hline Clinical seizures, $\%$ & 72.7 & 90.9 & 81.8 & n.s. \\
\hline Electrical seizures, \% & 27.3 & 81.8 & 54.5 & $<0.05$ \\
\hline \multicolumn{5}{|l|}{ aEEG, $\%^{*}$} \\
\hline - Normal & 9.1 & 0 & 4.5 & \\
\hline - Normalized $<48$ hours & 72.7 & 9.1 & 41.0 & \\
\hline - Abnormal > 48 hours & 18.2 & 90.9 & 54.5 & $<0.05$ \\
\hline Cranial US anomalies, $\%$ & 63.6 & 90.9 & 77.3 & n.s. \\
\hline Brain MRI severe anomalies, $\%$ & 18.2 & 72.7 & 45.5 & 0.005 \\
\hline Possible aetiology, $\%$ & 27.3 & 27.3 & 27.3 & n.s. \\
\hline Length of stay, days* & $\begin{array}{c}13.5 \\
(9.7-22.2)\end{array}$ & $\begin{array}{c}12.0 \\
(5-19)\end{array}$ & $\begin{array}{c}12.0 \\
(9-20.5)\end{array}$ & - \\
\hline
\end{tabular}

${ }^{*}$ Median (InterQuartile Range); $¥$ Al Naqeeb et $a^{R^{7}}$

aEEG: amplitude-integrated electroencephalogram; MRI: magnetic resonance imaging; LDH: lactic acid dehydrogenase; SUPC: sudden unexpected postnatal collapse; US: ultrasonography

2 - 32) and at a median of 4.4 hours after SUPC (range $0.5-18$ ) and strict targeted temperature management was maintained for 72 hours. Clinical, radiological and laboratory monitoring were applied according to the Portuguese Society of Neonatology protocol for perinatal HIE. ${ }^{25}$

Initial aEEG background activity showed abnormal amplitude in all except one patient: moderately abnormal in $18 \%$ and severely abnormal in $77 \%$. As to pattern classification, CNV was found in 5\%, DNV in 18\%, LV in 32\% and BS in $45 \%$.

Progression within 48 hours of $\mathrm{TH}$ to a normal aEEG background occurred in $45 \%$ (normal voltage and sleepwake cycling).

Electrical seizure activity was recorded in 55\%, while clinically apparent seizures were described in $82 \%$ of newborns.

Cranial ultrasonography abnormalities during the first 72 hours were described in $77 \%$ of our cases and these findings included edema and loss of gray/white matter differentiation $(77 \%)$ and increased echogenicity of basal ganglia and thalamus (54\%).

Abnormal brain MRI was identified in $54 \%$ of our cases. Minor abnormalities were present in $9 \%$ and moderate to severe hypoxic-ischemic injury in $46 \%$ patients. Findings consisted of combinations of abnormal signal intensity on one or more of sequences (T1, T2, diffusion) involving cerebral cortex, white matter, posterior limb of internal capsule, thalamus and basal ganglia. Two babies (9\%) did not perform MRI due to early fatal outcome and both had severe US abnormalities.

A search for potential causes of SUPC was performed for all babies, including infection, metabolic and cardiovascular screening. No cause was identified in $73 \%$ of cases. Some comorbidities that could relate to SUPC origin were identified in six cases $(27 \%)$ : early sepsis $(n=2)$, hypertrophic cardiomyopathy without left ventricle outflow obstruction ( $n=1)$, idiopathic persistent pulmonary hypertension with associated arterial hypertension $(n=1)$, type 1 laryngeal cleft $(n=1)$ and upper airway haemorrhage $(n=$ $1)$.

Half of the patients died, at a median of 12 days after birth (range 2 - 57). In most cases, death was related with the severity of the neurological injury, justifying life support withdrawal, after multidisciplinary discussion and parental participation.

The eleven surviving newborns were transferred to other medical units or discharged home at a median of 13.5 days after birth (range 6 - 30).

No significant complications related with the $\mathrm{TH}$ procedure were found, including central nervous system haemorrhage.

\section{DISCUSSION}

This study emphasises the circumstances and severity 
of SUPC events that occurred in Portugal after implementation of $\mathrm{TH}$ in $2009 .{ }^{18}$

We found an incidence of 2.7 cases per 100000 births during the study years, which is within the range of incidence described in the literature. ${ }^{1,4,6,10}$ We only included patients referred for $\mathrm{TH}$, so the real incidence estimate may lie above this value, since some patients may have not been referred for $\mathrm{TH}$, particularly during the earlier years after introduction of $\mathrm{TH}$. Our mortality rate was $50 \%$, which is similar to the rates indicated in the literature. ${ }^{6,10}$ Some reports estimate higher survival rates $(60 \%-73 \%),{ }^{1,4}$ most likely due to accessibility to advanced resuscitation and intensive care. ${ }^{6,10}$ Limitations on the reporting and differential access to non-consensual therapeutic interventions may influence the real incidence and modify conclusions regarding outcomes. ${ }^{1,4,6,8-10}$ Precise national data is not known and efforts should be made to acknowledge this reality, including the creation of a national registry for this clinical entity. Awareness of the possibility of its occurrence and regular training is also essential.

As expected and in accordance to its intrinsic definition, ${ }^{3,6,7}$ most infants were at term or near term, with no significant anticipated risks and with apparent good adaptation to extrauterine life. There was a trend for non-survivors to have been born from pregnancies with risk factors, even though the small number of patients precludes drawing robust conclusions. Gender, birthweight, gestational age and outborn status were not associated with survival. In addition, no significant difference was identified when comparing surviving and non-surviving patients in relation to the extent of resuscitation immediately after SUPC, the time of its occurrence and the time between the event and initiation of $\mathrm{TH}$.

All infants suffered the collapse in the first day, mostly $(73 \%)$ within the first two hours of life. These results are corroborated by other reports mentioning rates of $33 \%-73 \%$ for the first two hours. ${ }^{1,3,4,10}$ No patient was either referred to $\mathrm{TH}$ after the first postnatal day or started on $\mathrm{TH}$ more than six hours after the hypoxic insult.

The two infants with mild encephalopathy survived and the deceased infants had moderate to severe HIE, with higher Thompson scores $(p<0.005)$ and more intense metabolic acidosis $(p<0.05)$. There were no remarkable differences in hemodynamic status, kidney injury or laboratory cytolysis between the two groups.

Although there is a continuum showing increasing risk for encephalopathy along with deepening acidemia, ${ }^{31}$ its positive predictive value, sensitivity and specificity in predicting brain injury is known to be low. ${ }^{32}$ On the other side, the predictive values of the Thompson score system for neurological outcomes at one year are significant, particularly when the highest value and maintenance of abnormal signs are combined. ${ }^{30}$ This score consists of a simple clinical method of assessment of encephalopathy in neonates with perinatal asphyxia, including a neurological examination, assessment of respiration and fontanelle tension and taking into account the most severe signs and their persis- tence..$^{30,33}$ This method is strongly recommended for monitoring of HIE infants, and it is recognized as valuable to identify infants at higher risk of unfavourable outcomes. ${ }^{33,34}$

All deceased newborns except one had abnormal cranial US findings. This patient had severe encephalopathy, severe metabolic acidosis at admission $(\mathrm{pH} \mathrm{6.88}$, base deficit $25.9 \mathrm{mEq} / \mathrm{L}$ ), renal injury and cardiovascular instability, suppressed aEEG and died during the second day of life. Nevertheless, C-US is known for its low sensitivity and specificity in term HIE. ${ }^{35}$

Persistence of abnormal aEEG at 48 hours of TH was remarkably more common in non-survivors $(p<0.005)$, as well as electrical seizure activity $(p<0.05)$. The incidence of clinical seizures was identical between groups.

The great majority of newborns who died had moderate to severe brain MRI findings, with statistically significant differences compared to surviving patients.

In HIE, aEEG assessment consistently predicted neurodevelopmental outcomes at the age of one year, with strong association with the severity of abnormalities and its progression (specifically, normal voltage recovery and sleep-wake cycling). ${ }^{24,26,32,36}$ Certain MRI injury patterns have relevant prognostic and diagnostic value and novel techniques (such as diffusion weighted MRI and proton spectroscopy) act as potent predictors of neurological outcomes. ${ }^{37}$ Therefore, in SUPC cases, one might consider an identical interpretation about the prognostic value of aEEG and brain MRI findings as in the newborns exposed to $\mathrm{TH}$ in perinatal HIE. ${ }^{24,26,32,36-39}$

Possible causes were identified in $27 \%$ of cases. Reports on SUPC support this finding, describing that about $30 \%-50 \%$ of infants who suffer SUPC are subsequently recognised as having an underlying condition. ${ }^{1,5,6} \mathrm{~A}$ stratified risk assessment for infection, hypoglycaemia, metabolic diseases, pulmonary hypertension or congenital anomalies should be carried out. ${ }^{5,7} \mathrm{~A}$ post-mortem examination is recommended, even though most the death causes remain unexplained. ${ }^{6,7}$

Beyond aetiology, multiple predisposing conditions have been identified, suggesting that prevention may be possible in most cases. Implementation of structured strategies to minimize the risk of SUPC and timely assessment of risk factors are paramount. $1,2,8,9,31,40$

An important constraint to these goals is that the precise pathophysiology of SUPC is not completely understood. The triple risk hypothesis has been considered, underscoring the interplay between intrinsic and extrinsic factors during a critical developmental period: intrinsic vulnerability, positioning and lack of awareness. 1,3,6,9,10,14,41

As most SUPC cases occur in proximity to birth, infants must have an intrinsic susceptibility during the complex extrauterine adaptation, being less tolerant to hypoxia, blunting the arousal response (the role of oxytocin secretion, hormonal changes, brain immaturity, autonomic immature regulation with decreasing sympathetic tone and high pulmonary vascular resistance $)^{5,6,14}$ and being potentially exposed to maternal drugs during labour (e.g. opioids and 
magnesium sulphate). ${ }^{3,14,41}$

Positioning is one of the most relevant aspects and includes a combination of prone positioning, SSC, co-bedding, breastfeeding and maternal habitus. ${ }^{1,6,9,10,14,41}$

Infants who suffered from SUPC have been found prone in the mother's breast, chest or abdomen, swaddled and held supine by the mother, father or grandmother, lying beside a parent on the parent's bed or on their sides in the cot. $^{13,14}$ Lying prone on the breast or abdomen or laterally beside the mother's chest are the most frequently described scenarios. 1,4,8,9,41-43 These are potentially 'asphyxiating' attitudes, favoring airway obstruction, hypoventilation and suffocation by blocking the nostrils or by posterior displacement of the tongue. Additionally, maternal position or habitus/obesity may hinder the newborn attempts to relieve obstruction. ${ }^{1,6,9,10,14,41}$

In relation to SSC, studies are contradictory. $2,6,12,13,15,16,41$ European observational data demonstrated a rise in SUPC incidence following the implementation of routine SSC. ${ }^{6,41}$ In contrast, a systematic review concluded that this practice does not have apparent adverse short or long-term consequences, but the included trials had limited methodological quality. ${ }^{15}$ Indeed, a recent large study showed that increasing rates of breastfeeding initiatives and skin-to-skin care were, in fact, temporally associated with decreasing SUPC prevalence in the six days postbirth. ${ }^{2}$

In our sample, co-bedding was identified in $23 \%$ and an unsafe scenario, association with feeding and occurrence during SSC were found in more than half of the events.

Lack of awareness comprises the third important group of contributors to the risk: relative inexperience of mother, sleepiness, fatigue, sedation, dim lighting, unsupervised breastfeeding and infrequent observation by a healthcare professional. ${ }^{1,4,6,9,10,14,41,44}$ Distraction from mobile phone use has also been reported. 3,9

In accordance with the literature, our results showed a high prevalence of primiparous mothers. Inexperience in caring, holding the baby or breastfeeding and little knowledge on wellness signals, might partially explain this phenomenon. .,6,10,14 $^{2}$

Because developmental vulnerability of the infant cannot be modified and intrinsic factors may be difficult to identify before birth, it is critical that extrinsic conditions for SUPC are fully appreciated in order to reduce the risk of harm, while ensuring that benefits from safe SSC, breastfeeding and healthy bonding are preserved. .,6,14 $^{2}$

Several recommendations have emerged on these issues. Healthcare professionals should, on an immediate, ongoing and continued basis, observe the infants' breathing, activity, colour and tone, throughout the recovery period in the labour and delivery unit., 311,14 Surveillance of the infants' head, neck, nose, and mouth is critical for prevention of SUPC. In view of these facts, Ludington-Hoe et al developed a newborn assessment tool to pre-empt infant deterioration, incorporating safe position requirements and including 'respiratory', 'activity', 'perfusion' and 'position' $(R A P P)$ items. ${ }^{14}$ Years later, 'tone' assessment was added to the aforementioned tool, named as RAPPT, which was compared to the Apgar score to facilitate its adoption and to strengthen its effectiveness in predicting risk. ${ }^{11}$ Another postnatal surveillance protocol was recommended in an Italian centre, ensuring patency of the newborn airway and continuous monitoring of the dyad over the first two hours. 6,45

From a practical point of view, some authors believe that these interventions can be relatively intrusive, require human and technical resources and may not improve safety of the infant. ${ }^{6,14,46,47}$ Nevertheless, recent publications support their advantage, when implemented on an organized basis. $3,6,11,14,45$

Unobtrusive assessment during the moments of increased risk, namely when the mother or partner cannot sense the newborn wellbeing, has been encouraged as a rational way to improve safe care and it is now recommended by some recognized international and national organizations. ${ }^{6,14}$ The importance of healthcare personnel frequently checking on the infant's condition during the first 2 - 3 hours during SSC is emphasized, ensuring a safe position and non-occlusion of nose and mouth. ${ }^{6,16}$ Some statements strengthen the role of the healthcare professional and advise electronical monitoring (multi-parameter or pulse oximetry) if no appropriately trained person can remain in the room permanently. ${ }^{14,47}$

When prevention fails and the event ensues, it is essential for the clinician to acknowledge potential therapeutic interventions. In order to minimize injury from SUPC, therapeutic hypothermia is considered invaluable. ${ }^{17,19-23,48}$

While $\mathrm{TH}$ is a standard of care in term infants with intrapartum HIE, there is no clear evidence for its benefit after SUPC. The first trials on hypothermia excluded infants with postnatal collapse. Moreover, its infrequent occurrence, the uncertainty about its pathophysiology and lack of knowledge on the multiplicity of causes, precludes the design of a conclusive trial. ${ }^{6,18}$

Additionally, the potential lack of benefit and even risk of harm must be recognised, as in the case of infection, pulmonary hypertension, cardiac structural or dysrhythmic disorders, intracranial haemorrhage and some metabolic conditions, which may be adversely affected by functional changes induced by hypothermia. ${ }^{6,17,19,20}$

Despite these limitations, a few case reports on SUPC infants undergoing $\mathrm{TH}$ were published. ${ }^{6,9,17,19-23}$ Its use is supported on physiological mechanisms: approximately $75 \%$ of newborns with no established cause for collapse develop a typical post-asphyxia encephalopathy ${ }^{1,48}$ (evoking perinatal HIE), probably subsequent to a short but severe hypoxic insult from acute airway obstruction and cardiac arrest. ${ }^{1,48}$ Therefore, there is a plausible benefit from $\mathrm{TH}$ in these patients, which should be judiciously considered on an individual basis. Signed parental informed consent stating the potential benefit, despite the lack of evidence and alternatives, should be obtained in all cases.

Described short term outcomes after $\mathrm{TH}$ are variable and long term data are sparse..$^{6,9,17,19-21,23}$ Increasing 
experience and evolving investigation emphasize $\mathrm{TH}$ as a promising tool after SUPC. In our sample, no severe adverse effects directly related to $\mathrm{TH}$ were registered. Regarding outcomes, we found survival rates similar to those described in the literature, although long term neurodevelopment results have not been evaluated or compared yet and significant conclusions cannot be drawn.

The limitations of our study are its retrospective nature, the small sample size, the sparse description of clinical examination, the lack of knowledge on morbidity in the short and long term (concerning neurodevelopment, motor sequels and sensorial deficits), and, finally, the absence of data on outcomes of infants suffering SUPC who did not undergo $\mathrm{TH}$.

Inclusion of national results, the discussion of vital preventive strategies to implement in national institutions and the consideration of a promising intervention in such a serious condition, are some of the strengths of this paper.

Additionally, we aim to intensify awareness on SUPC circumstances and implications, so as to improve its prevention and favour quality of care to our newborns and their families.

\section{CONCLUSION}

In our national sample of 22 infants who suffered SUPC and underwent therapeutic hypothermia, a significant proportion had poor outcomes.

Lower Thompson scores, aEEG amplitude normalization and sleep-wake cycling before 48 hours of cooling and normal MRI seemed to be related with better outcomes, but the reduced number of patients included does not allow drawing definite conclusions.

Systematic reporting of SUPC events and long-term follow-up is important. Future research is needed in order to better understand the benefits of TH in this clinical entity. Its use is still considered on an individual basis, but actual evidence points to its general efficacy and safety.

SUPC is a rare but frequently fatal event and there is consensus regarding its potentially avoidable nature, through better recognition and avoidance of risk factors.

Adequate education and training of healthcare personnel and families on accurate newborn physiologic assessment and safe positioning, along with appropriate surveillance practices during the first hours of life should constitute a priority, whilst the benefits of breastfeeding and skin-toskin care should continue to be widely promoted.

\section{PROTECTION OF HUMANS AND ANIMALS}

The authors declare that the procedures were followed according to the regulations established by the Clinical Research and Ethics Committee and to the Helsinki Declaration of the World Medical Association, updated in 2013.

\section{DATA CONFIDENTIALITY}

The authors declare having followed the protocols in use at their working center regarding patients' data publication.

\section{COMPETING INTERESTS}

The authors have declared that no competing interests exist.

\section{FUNDING SOURCES}

This research received no specific grant from any funding agency in the public, commercial, or not-for-profit sectors.

\section{REFERENCES}

1. Becher J, Bhushan S, Lyon A. Unexpected collapse in apparently healthy newborns - A prospective national study of a missing cohort of neonatal deaths and near-death events. Arch Dis Child Fetal Neonatal Ed. 2012;97:2008-13.

2. Bartick M, Boisvert M, Philipp B, Feldman-Winter L. Trends in breastfeeding interventions, skin-to-skin care, and sudden infant death in the first 6 days after birth. J Pediatr. 2020;218:11-5.

3. Ferrarello D, Carmichael T. Sudden unexpected postnatal collapse of the newborn. Nurs Women's Heal. 2016;20:268-75.

4. Poets A, Steinfeldt R, Poets C. Sudden deaths and severe apparent life-threatening events in term infants within 24 hours of birth. Pediatrics. 2011;127:e869-73.

5. Parmigiani S, Hoffer L De. Sudden unexpected postnatal collapse: analysis of some clinical cases and their diagnostic approach. Ann Clin Case Rep. 2017;2:1301.

6. Monnelly V, Becher J. Sudden unexpected postnatal collapse. Early Hum Dev. 2018;126:28-31.

7. WellChild. The British Association of Perinatal Medicine. Guidelines for the investigation of newborn infants who suffer a sudden and unexpected postnatal collpase in the first week of life: Recommendations from a professional group on Sudden Unexpected postnatal collapse (London).; 011. [cited 2021 Jan 26]. Retrieved from: https://www.bapm. org/sites/default/files/files/SUPC_Booklet.pdf.

8. Dageville C, Pignol J, De Smet S. Very early neonatal apparent lifethreatening events and sudden unexpected deaths: Incidence and risk factors. Acta Paediatr Int J Paediatr. 2008;97:866-9.

9. Pejovic N, Herlenius E. Unexpected collapse of healthy newborn infants:

risk factors, supervision and hypothermia treatment. Acta Paediatr Int J Paediatr. 2013;102:680-8.

10. Herlenius E, Kuhn P. Sudden unexpected postnatal collapse of newborn infants: a review of cases, definitions, risks, and preventive measures. TransI Stroke Res. 2013;4:236-47.

11. Ludington-Hoe S, Morrison-Wilford B, DiMarco M, Lotas M. Promoting newborn safety using the RAPPT assessment and considering Apgar criteria: a quality improvement project. Neonatal Netw. 2018;37:85-95.

12. Abdulghani $\mathrm{N}$, Kristina $\mathrm{E}$, Amir $\mathrm{L}$. Worldwide prevalence of mother-infant skin-to-skin contact after vaginal birth: a systematic review. PLoS One. 2018;13:e0205696.

13. World Health Organization. Guideline: Protecting, promoting and supporting breastfeeding in facilities providing maternity and newborn services. Geneva: WHO; 2017.

14. Ludington-Hoe S, Morgan K. Infant assessment and reduction of sudden unexpected postnatal collapse risk during skin-to-skin contact. Newborn Infant Nurs Rev. 2014;14:28-33.

15. Moore E, Bergman N, Anderson G, Medley N. Early skin-to-skin contact for mothers and their healthy newborn infants (Review). Cochrane Database Syst Rev. 2016;11:CD003519.

16. Widström AM, Brimdyr K, Svensson K, Cadwell K, Nissen E. Skin-toskin contact the first hour after birth, underlying implications and clinical practice. Acta Paediatr. 2019;108:1192-204.

17. Smit E, Liu X, Jary S, Cowan F, Thoresen M. Cooling neonates who do not fulfil the standard cooling criteria - short- and long-term outcomes. Acta Paediatr Int J Paediatr. 2015;104:138-45.

18. Sampaio I, Graça AM, Moniz C. Hipotermia induzida na encefalopatia 
hipóxico-isquémica : da evidência científica à implementação de um protocolo. Acta Pediatr Port. 2010;41:184-90.

19. Thoresen M. Who should we cool after perinatal asphyxia? Semin Fetal Neonatal Med. 2015;20:66-71.

20. Cornet MC, Maton P, Langhendries JP, Marion W, Marguglio A, Smeets $\mathrm{S}$, et al. Use of therapeutic hypothermia in sudden unexpected postnatal collapse. Arch Pediatr. 2014;21:1006-10.

21. Marin N, Valverde E, Cabañas F. Episodio aparentemente letal neonatal durante el «piel con piel». Tratamiento con hipotermia. An Pediatr. 2013;79:253-6.

22. Ancora G. New frontiers in hypothermia. J Pediatr Neonatal Individ Med. 2013;2:1-5.

23. Filippi L, Laudani E, Tubili F, Calvani M, Bartolini I, Donzelli G. Incidence of sudden unexpected postnatal collapse in the therapeutic hypothermia era. Am J Perinatol. 2017;34:1362-7.

24. Thoresen M. Patient selection and prognostication with hypothermia treatment. Semin Fetal Neonatal Med. 2010;15:247-52.

25. Graça A, Pinto F, Vilan A, Dinis A, Sampaio I, Matos C, et al. Hipotermia induzida no tratamento da encefalopatia hipoxico-isquémica neonatal. Consenso nacional. Lisboa: Secção de Neonatologia da Sociedade Portuguesa de Pediatria; 2012.

26. al Naqeeb N, Edwards A, Cowan F, Azzopardi D. Assessment of neonatal encephalopathy by amplitude-integrated electroencephalography. Pediatrics. 1999;103:1263-71.

27. Graça A, Sampaio I, Moniz C, Machado MC. Electroencefalograma de amplitude integrada (aEEG) no recém-nascido com patologia neurológica - uma técnica a generalizar. Acta Pediatr Port. 2012;43:2029.

28. Hellström-Westas L, Rosén I, de Vries L, Greisen G. Amplitudeintegrated EEG classification and interpretation in preterm and term infants. Neoreviews. 2006;7:e76-87.

29. Sarnat H, Sarnat M. Neonatal encephalopathy following fetal distress: a clinical and electroencephalographic study. Arch Neurol. 1976;33:696705.

30. Thompson C, Puterman A, Linley L, Hann F, Elst C, Molteno C, et al. The value of a scoring system for $\mathrm{HIE}$ in predicting neurodevelopment outcome. Acta Paediatr. 1997;86:757-61.

31. Executive summary: Neonatal encephalopathy and neurologic outcome, second edition. Report of the American College of Obstetricians and Gynecologists' Task Force on Neonatal Encephalopathy. Obstet Gynecol. 2014;123:896-901.

32. Ahearne C, Boylan G, Murray D. Short and long term prognosis in perinatal asphyxia: an update. World J Clin Pediatr. 2016;5:67-75.

33. Biselele T, Naulaers G, Tady B. Evolution of the Thompson score during the first $6 \mathrm{~h}$ in infants with perinatal asphyxia. Acta Paediatr. 2014;103:145-8.

34. Horn A, Swingler G, Myer L, Linley L, Moegammad R, Joolay $Y$, et al. Early clinical signs in neonates with hypoxic ischemic encephalopathy predict an abnormal amplitude-integrated electroencephalogram at age
6 hours. BMC Pediatr. 2013;13:1-11.

35. Salas J, Tekes A, Hwang M, Northington F, Tuisman T. Head ultrasound in neonatal hypoxic-ischemic injury and its mimickers for clinicians : a review of the patterns of injury and the evolution of findings over time. Neonatology. 2018;114:185-97.

36. Thoresen M, Hellström-Westas L, Liu X, De Vries LS. Effect of hypothermia on amplitude-integrated electroencephalogram in infants with asphyxia. Pediatrics. 2010;126:131-9.

37. Thayyil S, Chandrasekaran M, Taylor A, Bainbridge A, Cady E, Chong $\mathrm{W}$, et al. Cerebral magnetic resonance biomarkers in neonatal encephalopathy : a meta-analysis. Pediatrics. 2010;125:e382-95.

38. Shankaran S, Barnes $P$, Hintz S, Laptook A, Zaterka-Baxter $K$ McDonald S, et al. Brain injury following trial of hypothermia for neonatal hypoxic-ischaemic encephalopathy. Arch Dis Child Fetal Neonatal Ed. 2012;97:398-405.

39. Cheong J, Coleman L, Hunt R, Lee K, Doyle L. Prognostic utility of magnetic resonance imaging in neonatal hypoxic-ischemic encephalopathy. Substudy of a randomized trial. Arch Pediatr Adolesc Med. 2012;166:634-40.

40. Raju T, Pemberton V, Saigal S, Blaisdell C, Moxey-Mims M, Buist S. Long-term healthcare outcomes of preterm birth: an executive summary of a conference sponsored by the National Institutes of Health. J Pediatr. 2017;181:309-18.

41. Andres V, Garcia P, Rimet Y, Nicaise C, Simeoni U. Apparent lifethreatening events in presumably healthy newborns during early skinto-skin contact. Pediatrics. 2011;127:e1073-6.

42. Gatti H, Castel C, Andrini P, Durand P, Carlus C, Chabernaud Jl, et al. Malaises graves et morts subites après une naissance normale à terme: à propos de six cas. Arch Pediatr. 2004;11:432-5.

43. Espagne S, Hamon I, Thiébaugeorges $\mathrm{O}$, Hascoet JM. Mort de nouveau-nés apparemment sains en salle de naissance: un problème de surveillance? Arch Pediatr. 2004;11:436-9.

44. Poets A, Urschitz MS, Steinfeldt R, Poets CF. Risk factors for early sudden deaths and severe apparent life-threatening events. Arch Dis Child Fetal Neonatal Ed. 2012;97:F395-7.

45. Davanzo R, De Cunto A, Paviotti G, Travan L, Inglese S, Brovedani P et al. Making the first days of life safer: preventing sudden unexpected postnatal collapse while promoting breastfeeding. J Hum Lact. 2015;31:47-52

46. Feldman-Winter L, Goldsmith JP. Safe sleep and skin-to-skin care in the neonatal period for healthy term newborns. Pediatrics. 2016;138:e20161889.

47. Smit M, Dawson JA, Ganzeboom A, Hooper SB, Van Roosmalen J Te Pas AB. Pulse oximetry in newborns with delayed cord clamping and immediate skin-to-skin contact. Arch Dis Child Fetal Neonatal Ed. 2014;99:309-15.

48. Silva S, Rocha P, Moinho R, Carvalho L, Sousa S, Diogo L, et al. Colapso súbito pós-natal no contacto pele-a-pele. Saude Infantil. 2018;40:76-9. 